\title{
Bryophytes of Mordovia State Nature Reserve (European Russia)
}

\author{
Irina V. Czernyadjeva ${ }^{1}$, Anna Mežaka ${ }^{2}$, Alexey D. Potemkin ${ }^{1}$ \\ ${ }^{1}$ Komarov Botanical Institute, Professor Popov Str., 2, St. Petersburg, 197376, Russia. \\ E-mail: irinamosses@yandex.ru, Potemkin_alexey@binran.ru \\ ${ }^{2}$ Department of Biosystematics, Institute of Life Sciences and Technologies, Daugavpils University, \\ Parādes street, 1A-101, Daugavpils, Latvia, LV-5400. \\ E-mail: anna.mezaka@biology.lv
}

\begin{abstract}
The present study compiles the results of bryophyte species inventories made at the Mordovia State Nature Reserve from 2014 till 2016. The reserve is located near southern limit of deciduous-coniferous forest subzone. In total 96\% of the reserve is covered by forests, where about half are pine forests. The annotated bryophyte checklist includes 142 moss species and 23 liverwort species. The data on collecting site characteristics, habitats, substrates, bryophyte species frequency, and sporophyte presence are provided. Presented treatment is a key contribution to the bryophyte flora of Mordovia and important for the knowledge on bryophyte distribution of this forested area within strongly anthropogenically disturbed European Russian landscape.
\end{abstract}

Keywords: flora; mosses; liverworts; Republic of Mordovia

\section{INTRODUCTION}

Mordovia State Nature Reserve with area of 32,162 ha is located in the Temnikovskyi District of the Republic of Mordovia, between $54^{\circ} 46^{\prime}-51^{\prime}$ $\mathrm{N}$ and $43^{\circ} 04^{\prime}-37^{\prime} \mathrm{E}$. The reserve represents a forest island within the middle of landscape of European Russia, which is strongly disturbed by the various agricultural activities. The bryophytes of the reserve until recently were poorly known. Most important study of the bryophytes of the reserve has been made by Kuznetsov (1960a), this study includes six liverwort and 71 moss species. Three species recorded by Kuznetsov (1960a) were not found by the authors of the present study: Fontinalis antipyretica Hedw., Plagiomnium affine (Blandow ex Funck) T.J.Kop., Sphagnum warnstorfii Russow. Drepanocladus kneifii Hedw. listed in Kuznetsov (1960a) is a synonym of Drepanocladus aduncus (Ignatov et al., 2006). Unfortunately, the herbarium of Kuznetsov was destroyed by a fire and his identifications are impossible to confirm. Data on bryophytes of the lime forests in the reserve were published recently, including 77 species (Czernyadjeva \& Mežaka, 2016). Records of new species for the reserve were published by Khapugin et al. (2011), Mežaka et al. (2013), Mežaka (2015), Mežaka \& Potemkin (2015), Czernyadjeva (2016a, 2016b), Grishutkin et al. (2016). The goal of our paper is to compile the results of recent bryophyte inventories made in the reserve in 2014, 2015 and 2016.

\section{MATERIAL AND METHODS}

\section{Study area}

Mordovia State Nature Reserve is a strictly protected area of the Republic of Mordovia. There is no discernible anthropogenic impact within its area. It is located in the eastern part of OkaDon Lowland of the Russian Plain, in Moksha River Basin, the right influx of Oka River. The altitude of Mordovia State Nature Reserve varies from $100 \mathrm{~m}$ to $191 \mathrm{~m}$ a.s.1. The soils of the reserve are composed of Middle Jurassic clay and sand deposits. The outcrops of limestones and dolomites of the Lower Permian and Upper Carboniferous occur in the valley of Satis River in the north-west of the reserve. Low-yield weakly podzolic sandy soils prevail in its territory. In the southwestern part of the reserve, chernozemlike floodplain soils are presented. Peat and peat-gleysolic soils are fairly widespread. The reserve is located in temperate continental climate. The average annual temperature is $+3.4^{\circ} \mathrm{C}$, the average temperature in January is $-12.4^{\circ} \mathrm{C}$, in July $+19.8^{\circ} \mathrm{C}$. The average annual precipitation is $530 \mathrm{~mm}$. The average thickness of snow layer is $50-60 \mathrm{~cm}$ (Gafferberg, 1960).

Mordovia State Nature Reserve is located near southern limit of deciduous-coniferous forests subzone. It is covered by coniferousdecidous forests. Considerable diversity of forest types is characteristic for the reserve and results in the diversity of bryophyte habitats. In total 
$96 \%$ of the reserve is covered by forests, about half of them are pine forests. Common are pine forests with mosses, blueberry, cowberry, Cladonia lichens, reed and Sphagnum. One fourth of all forests is covered by birch forests, often with significant amount of lime trees. The birch forests with sedge, herbs, blueberry and ferns are typical. The broad-leaved forests with lime, maple, oak, ash and elm are rather common. The mixed forests of several tree species are most typical at the reserve. The broad-leaved forests with herbs, hairy sedge and ferns frequently occur on nutrient rich soils. Broad-leaved forests with reed and bent-grass grow on dry, well drained soils. Broad-leaved forests with nettle occur on soils with high humidity and sufficient drainage. Some parts of the reserve are covered by aspen and spruce forests. The widest areas with spruce forests with ground-layer of blueberry, mosses, wood sorrel and ferns are located in over-floodplain terrace of Pushta River (Kuznetsov, 1960b; Kurnaev, 1968).

About $10 \%$ of the reserve is covered by wetlands. The forests with black alder, birch and spruce in tree layer and Phragmites australis, Carex acuta, Carex cespitosa, Filipendula ulmaria in the ground-layer occur in most of the wetlands with the high groundwater level. The transition mires and raised bogs are rare, covering karst and suffusion and aeolian cavities. Transient reed-grass, Sphagnum-sedge, Sphagnum-cotton-grass as well as sedge fens are found at the reserve. Floodplain communities, mostly with Alnus glutinosa, cover the river floodplains, where understory consists mostly of bird-cherry, buckthorn, raspberry, nettle, dropwort, kingcup, marsh-bedstraw, reed-grass (Kuznetsov, 1960b; Kurnaev, 1968).

Grasslands occupy less than $1 \%$ of the reserve and occur as small patches among forest areas (Kuznetsov, 1960b; Kurnaev, 1968).

\section{Field methods}

The present study is based on the field inventories done in July 2014, July and October 2015, July 2016 in vicinity of Pavlovsky, Steklyanny, Srednyaya Melnitsa, Inorsky, Novenkovsky cordons, and village Pushta, in all habitats (Fig. 1). In total about 1500 samples of bryophytes were collected. The particular attention was devoted to the moss collection. Liverworts of the reserve need an additional study. The bryophyte speci-

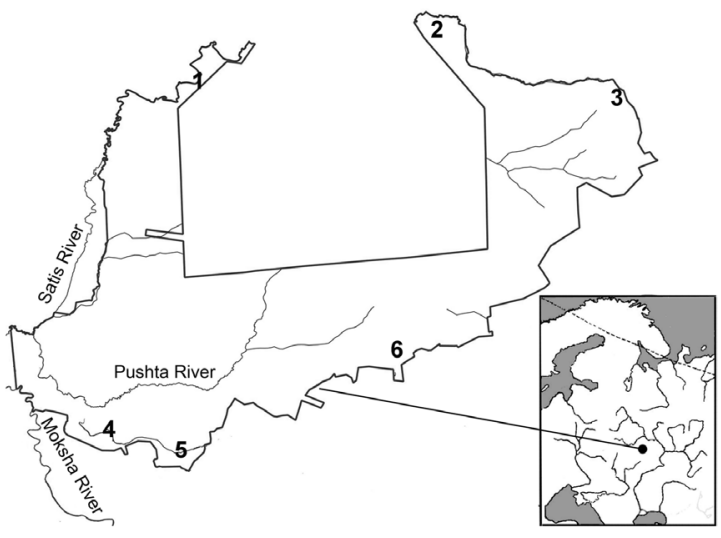

Fig. 1. Location of the Mordovia State Nature Reserve and collection sites: 1 - vicinity of cordon Srednyaya Melnitsa, $54^{\circ} 54^{\prime} \mathrm{N}, 43^{\circ} 14^{\prime} \mathrm{E}$; 2 - vicinity of cordon Novenkovsky, $54^{\circ} 46^{\prime} \mathrm{N}, 43^{\circ} 24^{\prime} \mathrm{E}$; 3 vicinity of cordon Steklyanny, $54^{\circ} 53^{\prime} \mathrm{N}, 43^{\circ} 36^{\prime} \mathrm{E}$; 4 - vicinity of cordon Inorsky, $54^{\circ} 43^{\prime} \mathrm{N}, 4^{\circ} 07^{\prime} \mathrm{E}$; 5 - vicinity of village Pushta, $54^{\circ} 43^{\prime} \mathrm{N}, 43^{\circ} 14^{\prime} \mathrm{E}$; 6

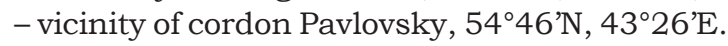

mens are deposited at the herbarium of Komarov Botanical Institute, St. Petersburg (LE) and at the herbarium of Mordovia State Nature Reserve.

\section{RESULTS}

The study presents the bryophyte (liverwort and moss) checklist, annotated by numbers of collection sites, habitats, substrate, frequency, and presence of sporophytes. Nomenclature for mosses follows Ignatov et al. (2006) and for liverworts Potemkin \& Sofronova (2009). Bryophyte species frequency was defined on the basis of the field observations and laboratory studies as follows: rare - a species recorded 1-3 times, sporadically $-4-7$, frequent - over 7 times.

\section{MARCHANTIOPHYTA}

BLASIA PUSILLA L. - 1. Rare. On railway embankment.

Blepharostoma tRichophyllum (L.) Dumort. - 3. Rare. On decaying wood in mixed forest.

CAlypogeia muelleriana (Schiffn.) Müll. Frib. - 1, 6. Rare. On decaying wood on creek bank. Calypogeia sphagnicola (Arnell \& J.Perss.) Warnst. \& Loeske - 6. Rare. On creek bank. 
Cephalozia Bicuspidata (L.) Dumort. - 2, 3, 6. Sporadically. On decaying wood in dry pine and pine-birch forest; on creek bank.

Cephalozia lunulifolia (Dumort.) Dumort. s.1. -3 , 6. Sporadically. On decaying wood in spruce forest with moderate moisture; on creek bank. Collected plants were sterile, that does not permit to differentiate them from related $C$. affinis Lindb.

Chiloscyphus minor (Nees) J.J.Engel \& R.M.Schust. -1 . Rare. On bark of alive lime and dead lime log in broad-leaved forest.

Chiloscyphus Pallescens (Ehrh. ex Hoffm.) Dumort. - 3, 6. Sporadically. On soil of creek bank; on decaying wood in spruce forest.

Chiloscyphus profundus (Nees) J.J.Engel \& R.M.Schust. - 1-6. Frequent. On tree bark and decaying woods of broad-leaved, swamp, coniferous and deciduous forests.

CRossocalyx hellerianus (Nees ex Lindenb.) Meyl. - 3. Rare. On decaying log.

FrulLANIA BOLANDERI Austin - 3, 4. Sporadically. On maple, elm and lime bark in broadleaved forests.

Syzygiella AUTumnalis (DC.) Feldberg, Váňa, Hentschel \& Heinrichs [Jamesoniella autumnalis (DC.) Steph.] - 1, 3, 6. Rare. On decaying wood of spruce, pine and aspen in mixed broad-leaved forests.

MARCHANTIA POLYMORPHA L. - 1 , 3. Rare. On soil in wet bush habitat; on dolomite quarry; near to creek.

MetZGeria furcata (L.) Corda - 1. Rare. On lime bark in broad-leaved forest.

Lophozia gutTulata (Lindb. et Arnell) A. Evans [L. longiflora auct. non (Nees) Schiffn. (Damsholt, 2002; Potemkin \& Sofronova, 2009)] -6 . Rare. On decaying wood in mixed forest.

Pellia endivilfolia (Dicks.) Dumort. - 1. Rare. Creek bank; on stone.

Pellia EPIPHYlla (L.) Corda-2, 4, 5. Sporadically. On wet soil in different habitats; on bank of creek Arga.

Plagiochila PORElloides (Torr. ex Nees) Lindenb. -5 . Rare. On soil in high grass spruce forest.

PTILIDIUM PULCHERRIMUM (Weber) Vain. - 2, 4, 6. Frequent. On decaying wood, maple, lime in mixed spruce-lime forests; on basal part of birch stem in swamp forest; on basal part of pine in pine forest; on aspen bark in mixed forest.

Radula complanata (L.) Dumort. - 3, 4. Sporadically. On lime, maple, aspen bark in broadleaved forests.
Riccia Fluitans L. - 6. Rare. Among grass roots on pond bank.

RICCIA HUEBENERIANA Lindenb. - 6. Rare. On dried soil of forest road.

SCAPANIA IRRIGUA (Nees) Nees - 3. Rare. On railroad slope.

\section{BRYOPHYTA}

ABietinella ABIEtina (Hedw.) M.Fleisch. - 1. Rare. On decaying wood in mixed forest; on bare soil on slope; on roadsides.

Amblystegium serpens (Hedw.) Bruch, Schimp. \& W.Gümbel - 1-5. Frequent. On decaying wood, at the base of trunks, rarely on soil in lime, pine, spruce forests and mixed forests, on stream and river banks; on bare soil of roadsides. With sporophytes.

AnOMOdon atTEnuAtus (Hedw.) Huebener - 1, 4, 5 . Rare. At the base of trunks especially on maple and lime in floodplain black alder forests and in mixed broad-leaved forest.

ANOMOdon LONGifolius (Brid.) C.C.Hartm. - 1, 3-5. Frequent. At the base of trunks especially on lime, maple in broad-leaved forests, mixed broad-leaved forests and in floodplain black alder forests.

AnOmodon viticulosus (Hedw.) Hook. \& Taylor $-1,4$. Rare. At the base of trunks in broadleaved forests and in floodplain black alder forest.

ATRICHUM FLAVISETUM Mitt. - 3, 4. Rare. On soil in mixed forest; on decaying wood in swamp habitat. With sporophytes.

Atrichum tenellum (Roehl.) Bruch, Schimp. \& W.Gümbel - 1, 3-6. Frequent. On bare soil on roadsides; on bare soil under roots of fallen trees; in disturbed habitats. With sporophytes.

Atrichum undulatum (Hedw.) P.Beauv. - 1, 3-6. Frequent. On bare soil in roadsides and disturbed habitats; on bare soil under roots of fallen trees in forests; rarely on hummock in swamp forest. With sporophytes.

Aulacomnium Palustre (Hedw.) Schwägr. - 2-4, 6 . Frequent. On hummocks of sedgeSphagnum association wetlands; on soil of swamp-mixed forests; on ditch; on fallen tree root; roadsides; in coniferous forests.

Barbula convoluta Hedw. - 1. Rare. On slope; on stone on roadside. With sporophytes.

Barbula unguiculata Hedw. - 1, 3. Rare. On slope; on bare soil on roadside; in disturbed habitats. With sporophytes. 
BRACHYTHECIASTRUM VELUTinum (Hedw.) Ignatov \& Huttunen - 1, 3-6. Frequent. On decaying wood, at the base of trunks, not frequent on bare soil under roots of fallen trees, in lime, spruce, floodplain black alder and mixed forests. With sporophytes.

BRACHYTHECIUM ALBICANS (Hedw.) Schimp. - 1, 3 . Rare. On road at old quarry; on old road.

BRACHYTHECIUM MILDEANUm (Schimp.) Schimp. ex Milde - 3, 5. Rare. At the base of trunks in floodplain black alder forest; on roadsides; on wet soil of ditch bank. With sporophytes.

BRACHYTHECIUM Rivulare Bruch, Schimp. \& W.Gümbel - 1. Rare. On soil of stream bank; on dolomite stone.

BRACHYTHECIUM RotAEANUm De Not. - 4. Rare. On maple bark in floodplain black alder forest. With sporophytes.

BRACHYTHECIUM RUTABUlum (Hedw.) Schimp. -1 . Rare. On decaying wood in forest.

BRACHYTHECIUM SALEBROSUM (F.Weber \& D.Mohr) Schimp. - 1, 3-6. Frequent. On decaying wood, at the base of trunks, on tree bark, not frequent on soil in lime, spruce, mixed broad-leaved and pine forests. With sporophytes.

BRyum ARGENTEUm Hedw. - 1. Rare. On cement escarpment of Svyatoy source Serafima Sarovskovo.

Bryum CAESPITICIUM Hedw. - 3. Rare. On soil in dry pine forest.

Bryum Elegans Nees ex Brid. - Rare. On soil in dry pine forest.

BRYum LONCHOCAUlon Müll. Hal. - 1, 3. Rare. On bare soil of roadsides and stream bank. With sporophytes.

BRYUM MORAVICUM Podp. - 1, 3-5. Sporadically. At the base of trunks, on decaying wood, on tree bark in spruce, lime and mixed broadleaved forests; on bare soil of pits and fallen tree roots.

Bryum Pallens Sw. ex anon. - 3. Rare. On bare soil in disturbed habitats. With sporophytes.

Bryum PSEudotriquetrum (Hedw.) P. Gaertn. et al. - 4. Rare. On river bank.

BuXBAUMIA APHYLla Hedw. - 2-4, 6. Sporadically. On bare soil of roadsides. With sporophytes.

Callicladium haldanianum (Grev.) H.A. Crum 1, 3-6. Frequent. At the base of trunks, on decaying wood, on tree bark in spruce, lime and mixed broad-leaved forests and in floodplain black alder forests. With sporophytes.
Calliergon cordifolium (Hedw.) Kindb. - 1-4, 6. Sporadically. On river and stream banks, on soil of wetland forests, floodplain black alder forests; in dried puddle. With sporophytes.

Calliergonella cuspidata (Hedw.) Loeske - 1 , 4, 6. Rare. On pit wall close to the source of water flow; on decaying wood; in swamp bush; dolomite quarry; on roadside; in disturbed habitats.

CAlliergonella lindbergi (Mitt.) Hedenäs - 1, 3 , 4. Sporadically. On decaying wood in swamp birch forest; on bare soil in disturbed habitats.

CAmpyliadelphus chrysophyllus (Brid.) R.S. Chopra - 3, 6. Rare. On dead driftwood on river banks in lime forest; in humid pit walls.

CAmpylidium Calcareum (Crundw. \& Nyholm) Hedenäs - 1. Sporadically. On stones of river banks; on stones and bare soil of karst. With sporophytes.

CAMPYLIDIUM SOMMERFELTiI (Myrin) Ochyra - 1-6. Frequent. At the base of trunks, on decaying wood in spruce, lime and mixed broadleaved forests. With sporophytes.

Ceratodon purpureus (Hedw.) Brid. - 1, 3-5. Frequent. On bare soil of disturbed habitats; on roadsides; fallen tree roots; at the base of trunks in lime forest. With sporophytes.

CirRiphyllum Piliferum (Hedw.) Grout - 1, 4, 5. Rare. On soil of spruce forest; on decaying wood and on stump in swamp forest with willows and birches.

Climacium dendroides (Hedw.) F. Weber \& D. Mohr-3-6. Sporadically. On soil, at the base of trunks, not frequent on decaying wood in birch or spruce forests, floodplain black alder forest; on bare soil of transition zone between deciduous and coniferous forests.

Cratoneuron filicinum (Hedw.) Spruce - 1, 3. Rare. On soil of river banks; on the dolomite gravel at water source.

Dichodontium Pellucidum (Hedw.) Schimp. - 1 . Rare. On the stone at the river bank.

Dicranella CERviculata (Hedw.) Schimp. - 3, 6. Rare. On bare soil under roots of fallen trees at wet spruce forest; on roadsides. With sporophytes.

Dicranella Heteromalla (Hedw.) Schimp. - 2-6. Frequent. On bare soil under roots of fallen trees, on roadsides, on stream bank. With sporophytes. 
Dicranum Bonjeani De Not. - 3, 6. Rare. At the base of trunks in spruce forest; on ditch walls.

DicRanum Flagellare Hedw. - 4, 6. Sporadically. On the decaying wood and on basal part of tree stems in spruce and lime forests.

DicRAnum fuscescens Turner - 5. Rare. On the basal part of tree trunk in spruce forest.

DicRANum MONTANum Hedw. - 1-6. Frequent. On decaying wood, at the base of trunks, on tree bark in lime, birch, spruce, pine forests, mixed forests, floodplain black alder forests; on decaying wood in sedge-Sphagnum wetland. With sporophytes.

DicRANUM POLYSETUM Sw. - 1, 3-6. Frequent. On soil and decaying wood in lime, spruce, birch and mixed forests, floodplain black alder forests. With sporophytes.

DiCRANUM SCOPARIUM Hedw. - 1, 3-6. Frequent. On soil, at the base of trunks, on decaying wood in lime, pine, spruce, birch and mixed forests, floodplain black alder forests, on hummocks in wetland. With sporophytes.

DiCRANUM VIRIDE (Sull. \& Lesq.) Lindb. - 1-4, 6. Sporadically. On bark of trees: in lime, mixed and floodplain black alder forests.

Didymodon fallaX (Hedw.) R.H. Zander -1 . Rare. On stones of gravelly slopes, dolomite quarry.

DiDYMODON RIGIDULUS Hedw. - 1, 6a. Rare. On stone of the river bank; on bare soil, on stone of lake bank. With sporophytes.

DitRICHUM CYLINDRICUM (Hedw.) Grout - 1, 5, 6 . Rare. On bare soil of roadsides; on river banks. With sporophytes.

DitRICHUM HETEROMALlum (Hedw.) E. Britton -6 . Rare. On bare soil of roadsides. With sporophytes.

DitRICHUM PUSILlum (Hedw.) Hampe - 5. Rare. On bare soil of roadsides. With sporophytes.

Drepanocladus aduncus (Hedw.) Warnst. - 3-4, 6. Sporadically. On soil of mixed floodplain forest and in sedge-Sphagnum wetland; on walls of pits with water.

DREPanocladus Polygamus (Bruch, Schimp. \& W.Gümbel) Hedenäs - 4-6. Sporadically. On decaying wood in floodplain black alder and mixed forest; on walls of pit with water. With sporophytes.

EURHYNCHIASTRUM PULCHELlUM (Hedw.) Ignatov \& Huttunen - 1, 3. Rare. At the base of trunks in floodplain mixed lime forest; on wet soil of karst pit walls; on dolomite stone.
Fissidens BRYOIDES Hedw. - 1, 3, 4. Sporadically. On bare soil under roots of fallen trees; on ditch walls and karst pits; on decaying wood at river and ditch banks; on decaying wood at floodplain black alder forest. With sporophytes.

Fissidens EXIGUUS Sull. - 1. Rare. On stone of river bank. With sporophytes.

Fissidens GRACILIFOLIUs Brugg.-Nann. \& Nyholm - 1. Rare. On stone of river bank; on stone of karst pit. With sporophytes.

Fissidens TAXIFOLIUS Hedw. - 1. Rare. On dolomite stone of the creek; on soil of lime forest; on stone and bare clay soil of river bank.

FunARIA HYGROMETRICA Hedw. - 1, 3-5. Sporadically. On bare soil on disturbed habitats; on roadsides. With sporophytes.

Herzogiella SELIGeri (Brid.) Z. Iwats. - 1-3, 6. Rare. On dead branches and logs in mixed lime forests. With sporophytes.

HERZOGIELla tURFACEA (Lindb.) Z. Iwats. - 1. Rare. On dead branch in mixed lime forest. With sporophytes.

Homalia tRichomanoides (Hedw.) Bruch, Schimp. $\&$ W.Gümbel - 1, 3, 4, 5. Sporadically. On tree bark, at the base of trunks in broadleaved forests, mixed forests, floodplain black alder forests. With sporophytes.

HygROAmblystegium HUmile (P. Beauv.) Vanderp., Goffinet \& Hedenäs - 1, 4. Rare. At the base of trunks in floodplain lime, mixed forest and black alder forests.

Hygroamblystegium VARIUm (Hedw.) Mönk. - 3, 5 . Rare. On soil of floodplain black alder forest; on ditch walls with water. With sporophytes.

Hylocomium splendens (Hedw.) Bruch, Schimp. \& W.Gümbel-3, 5, 6. Sporadically. On soil, on decaying wood, at the base of trunks in lime, spruce and mixed forests.

HyPNUM CUPRESSIFORME Hedw. - 1, 3-6. Rare. At the base of trunks, on decaying wood in broad-leaved forests.

LEPTOBRYUM PYRIFORME (Hedw.) Wilson - 3, 5. Rare. On bare soil in broad-leaved forest; on decaying wood in lime forest. With sporophytes.

LEPTODICTYUM RIPARIUM (Hedw.) Warnst. - 1-5. Frequent. On river and stream banks; on walls of ditches; on humid soil in floodplain black alder and birch forests. With sporophytes.

LESKEA POLYCARPA Hedw. - 1, 4-6. Frequent. On tree bark, at the base of trunks, on decay- 
ing wood in mixed and broad-leaved forests, in floodplain habitats, on river banks. With sporophytes.

LEuCOdOn Sciuroides (Hedw.) Schwägr. - 1, 4, 5. Rare. On bark of lime, maple, aspen in broad-leaved and mixed forests; on bark of maple in floodplain black alder forest; on bark of black alder on river bank.

Mnium LYCOPODiOIDEs Schwägr. - 4. Rare. On bare soil in floodplain black alder forest.

Mnium Stellare Hedw. - 1, 5. Sporadically. On bare soil under roots of fallen trees in spruce forest; at the base of trunks in floodplain lime forest; on karst pit wall.

Myrinia PUlvinata (Wahlenb.) Schimp. - 1, 4. Rare. On bark of bird-cherry tree on river bank and on bark of young lime in broadleaved forest.

NeCKera PENNATA Hedw. - 1, 3-6. Sporadically. On tree bark and at the base of trunks in lime and mixed broad-leaved forests. With sporophytes.

ORTHOTRICHUM OBTUSIFOLIUM Brid. - 1, 3, 4. Sporadically. On tree bark and at the base of trunks in lime and mixed broad-leaved forests; on bark of bird-cherry tree on river bank. With sporophytes.

ORTHOTRICHUM AFFINE Brid. - 1. On tree bark of aspen, lime and maple in aspen mixed forest.

ORTHOTRICHUM PALLENS Bruch ex Brid. - 5. Rare. On lime bark in broad-leaved forest. With sporophytes.

ORTHOTRICHUM SPECIOSUM Nees - 1, 3-6. Frequent. On tree bark and at the base of trunks in lime, spruce and mixed broad-leaved forests, in floodplain habitats. With sporophytes.

OXYRRHYNCHIUM HIANS (Hedw.) Loeske - 1, 4, 5. Sporadically. On soil and decaying wood in spruce and floodplain black alder forests; on bare soil in roadsides; on dolomite stone; on pit walls; on stream bank; on stones of river bank and on karst pit.

Physcomitrella Patens (Hedw.) Bruch, Schimp. \& W. Gümbel - 4. Rare. On bare soil of roadside. With sporophytes.

PhySCOMITRIUM SPHAERICUM (C.F.Ludw. ex Schkuhr) Brid. - 4. Rare. On bare soil of roadside. With sporophytes.

Plagiomnium curvatulum (Lindb.) Schljakov -3. Rare. On ditch walls and roadsides.

Plagiomnium cuspidatum (Hedw.) T.J. Kop. - 1, 3-6. Frequent. On soil, on decaying wood, on tree bark and on basal part of tree bark in lime, birch, spruce, mixed broad-leaved, floodplain black alder forests and on river banks. With sporophytes.

Plagiomnium elatum (Bruch \& Schimp.) T.J. Kop. -3 . Rare. In depression of deciduous forest.

Plagiomnium ellipticum (Brid.) T.J. Kop. - 1, 4, 5. Sporadically. On soil and at basal part of tree stem in lime, spruce and floodplain black alder forest, on river banks.

Plagiomnium medium (Bruch, Schimp. \& W. Gümbel) T.J. Kop. - 1, 4, 5. Sporadically. On decaying wood in broad-leaved forest; on bare soil of roadsides. With sporophytes.

Plagiomnium Rostratum (Schrad.) T.J. Kop. -3. Rare. On bare soil in disturbed habitats.

Plagiothecium CAVIFOLIUM (Brid.) Z.Iwats. - 1, 4, 5, 6 . Rare. On decaying wood in swamp birch forest; at the base of trunks on stream bank. Plagiothecium denticulatum (Hedw.) Bruch, Schimp. \& W.Gümbel-1-6. Frequent. At the base of trunks, on decaying wood in lime, pine, spruce, mixed broad-leaved forests, floodplain habitats, on river banks. With sporophytes.

Plagiothecium laetum Schimp. - 1, 3, 5, 6. Frequent. At the base of trunks, on decaying wood in lime, spruce and mixed broad-leaved forests, on river banks. With sporophytes.

Plagiothecium latebricola Bruch, Schimp. \& W.Gümbel - 1, 4, 6. Sporadically. At the base of trunks, on decaying wood in lime, mixed broad-leaved and floodplain black alder forests.

Platygyrium Repens (Brid.) Bruch, Schimp. \& W.Gümbel-1, 3-6. Frequent. On tree bark, at the base of trunks, on decaying wood in lime, spruce, mixed broad-leaved, floodplain black alder forests, on river banks.

Pleurozium SCHReberi (Brid.) Mitt. - 1, 3-6. Frequent. On soil, on hummock, at the base of trunks, on decaying wood in lime, spruce, swamp and mixed broad-leaved forests, in floodplain habitats.

Pogonatum URnigerum (Hedw.) P.Beauv - 6. Rare. On bare soil of roadside.

Pohlia ANDALUSICA (Hoehnel) Broth. - 6. Rare. On bare soil of roadside.

Pohlia annotina (Hedw.) Lindb. - 1, 3, 5, 6. Sporadically. On bare soil of roadside; in disturbed habitats; on river banks.

Pohlia BulbifERA (Warnst.) Warnst. - 1, 6. Rare. On bare soil of roadside. 
PoHLIA FILum (Schimp.) Mårtensson - 5. Rare. On bare soil of roadside.

Pohlia nutans (Hedw.) Lindb. - 1, 3, 4, 6. Frequent. On bare soil under roots of fallen trees, on decaying wood, at the base of trunks in pine, spruce, mixed broad-leaved forests, floodplain black alder forests, on hummocks of sedge-Sphagnum wetlands; on river banks. With sporophytes.

PoHLIA PROLIGERA (Kindb.) Lindb. \& Broth. - 1 . Rare. On bare soil of river bank.

Polytrichum commune Hedw. - 3-6. Frequent. On soil, less frequent on decaying wood in spruce and mixed forests, swamp habitats; in disturbed habitats.

Polytrichum Densifolium Wilson ex Mitt. - 4, 6. Rare. On bare soil under roots of fallen trees in spruce forest; on hummock in mixed floodplain forest. With sporophytes.

POLYTRICHUM JUNIPERINUM Hedw. - 3-6. Sporadically. On soil and decaying wood in pine, spruce, lime, mixed and swamp forests; on bare soil of disturbed habitats. With sporophytes.

POLYTRICHUM LONGisetum Sw. ex Brid. var. LONGISETUM $-3,4,6$. Sporadically. On decaying wood in lime forest and in swamp habitat; on bare soil under roots of fallen trees in spruce forest.

POLYTRICHUM LONGISETUM var. ANOMALUM (Milde) G.L.Sm. - 6a, 4. Rare. On bare soil under roots of fallen trees in spruce forest; on soil of mixed floodplain forest.

POLYTRICHUM PALLIDISETUM Funck - 3. Rare. On bare soil under roots of fallen trees in spruce forest.

Polytrichum piliferum Hedw. - 1, 3. Rare. On bare soil of roadsides and in disturbed habitats.

POLYTRICHUM STRICTUM Brid. - 6. Rare. On hummocks in sedge-Sphagnum wetland. With sporophytes.

PsEUdOBRYum CINCLIDIOIDES (Huebener) T.J. Kop. - 6. Rare. On soil at river bank.

Pseudoleskeella Nervosa (Brid.) Nyholm - 1, 3-6. Frequent. On tree bark, on decaying wood, at the base of trunks in lime, mixed broad-leaved, deciduous, floodplain black alder forests; on tree bark at river banks.

PterigynandRum Filiforme Hedw. - 1 . Rare. On bark of lime in lime, broad-leaved and mixed broad-leaved forests.

PTILIUM CRISTA-CASTRENSIS (Hedw.) De Not. - 3, 6. Rare. On soil in spruce forest.
Pylaisia polyantha (Hedw.) Bruch, Schimp. \& W. Gümbel - 1-6. Frequent. On tree bark, on decaying wood, at the base of trunks in lime, pine, mixed broad-leaved, spruce and floodplain black alder forests; on tree bark at river banks. With sporophytes.

PYLAISIA SELWYNII Kindb. -3 . Rare. On bark of lime in lime forest. With sporophytes.

Rhizomnium Punctatum (Hedw.) T.J. Kop. - 1, 3-6. Sporadically. On soil, hummock and decaying wood in lime, spruce, swamp, deciduous, floodplain black alder forests.

Rhodobryum Roseum (Hedw.) Limpr. -2-4. Rare. On bare soil of roadsides.

RHODOBRYum ONTARIENSE (Kindb.) Kindb. - 4. Rare. On soil in spruce forest.

RHYTIDIADELPHUS TRIQUETRUS (Hedw.) Warnst. - 1 , $3,4,6$. Sporadically. On decaying wood and at the base of trunks in lime, mixed broadleaved, floodplain forests and in wetland with Sphagnum.

SANionia Uncinata (Hedw.) Loeske - 1-6. Frequent. On decaying wood, at the base of trunks, on tree bark in lime, pine, mixed broad-leaved, spruce and floodplain black alder forests. With sporophytes.

Schistostega pennata (Hedw.) F. Weber et D. Mohr - 1, 3, 6. Rare. On bare soil under roots of fallen trees in spruce and mixed forests; on bare soil at stream bank. With sporophytes.

SCIURO-HYPNUM CURTUM (Lindb). Ignatov - 1, 4-6. Frequent. On soil, decaying wood, at the base of trunks in lime, mixed broad-leaved, spruce forests; on hummocks in sedgeSphagnum wetland; on dolomite stones in quarry. With sporophytes.

SCIURO-HYPNUM POPULEUM (Hedw.) Ignatov \& Huttunen - 3. Rare. At the base of trunks in mixed forest.

SCIURO-HYPNUm REFLEXUM (Starke) Ignatov \& Huttunen - 1, 3-6. Frequent. On decaying wood, at the base of trunks in lime, mixed broad-leaved, spruce, floodplain black alder forests. With sporophytes.

SCIURO-HYPNUM STARKEI (Brid.) Ignatov \& Huttunen $-3,6$. Rare. On decaying wood in lime and mixed broad-leaved forests.

Serpoleskea subTilis (Hedw.) Loeske - 1, 3-6. Frequent. On decaying wood, at the base of trunks, on tree bark in lime, mixed broadleaved and floodplain forests; on stones at river banks. With sporophytes. 
Sphagnum Angustifolium (C.E.O. Jensen ex Russow) C.E.O. Jensen - 1, 3, 4, 6. Sporadically. On sedge-Sphagnum wetlands. With sporophytes.

SPHAGNum ANNULATUM Warnst. - 6. Rare. On sedge-Sphagnum wetlands.

Sphagnum CAPILlifolium (Ehrh.) Hedw. - 3, 6. Sporadically. On Sphagnum wetlands; in spruce and swamp forests; on stream banks.

Sphagnum Centrale C.E.O. Jensen - 3, 4, 6. Sporadically. On hummocks of cotton grassSphagnum wetlands; in mixed swamp and moderately wet pine forests.

Sphagnum compactum Lam. \& DC. - 6. Rare. On sedge-Sphagnum wetland.

SPHAGNum CUSPIDATUM Ehrh. ex Hoffm. - 3, 6. Rare. On sedge-Sphagnum wetland and mixed swamp forest.

SPHAGNum FallaX (H.Klinggr.) H. Klinggr. - 3, 4, 6. Sporadically. On sedge-Sphagnum and cotton-grass-Sphagnum wetlands, on mixed forest; on stream banks.

SPHAGNUM FIMBRIATUM Wilson - 4, 6. Sporadically. On cotton-grass-Sphagnum wetlands; on river bank. With sporophytes.

Sphagnum flexuosum Dozy \& Molk. - 4, 6. Sporadically. On sedge-Sphagnum wetland and spruce forest with Sphagnum; on bank creek.

Sphagnum GIRGENSOHNiI Russow - 3, 4, 6. Sporadically. On sedge-Sphagnum wetland and in mixed forest with Sphagnum, swamp forest.

Sphagnum Magellanicum Brid. - 3, 6. Sporadically. On hummocks of sedge-Sphagnum and cotton-grass-Sphagnum wetlands and spruce forest with Sphagnum, swamp forest.

Sphagnum PAlustre L. $-3,4$, 6. Rare. In sedgeSphagnum wetland; in swamp forest with Sphagnum, swamp forest with birch.

SPHAGNUM RIPARIUM Ångstr. - 6. Rare. On river bank; on burned karst. With sporophytes.

SPHAGNum RUBELLUM Wilson - 3. Rare. On hummock of swamp margin.

SPHAGNUM RUSSOWII Warnst. - 3, 6. Sporadically. On sedge-Sphagnum wetland and birch swamp forest.

SPHAGNUM SQUARROSUm Crome $-3,4,6$. Sporadically. On sedge-Sphagnum wetland, swamp forest with birch, moderately wet forest with birch and pine; in karst pit of dry coniferous forest; on stream banks. With sporophytes.

Sphagnum subsecundum Nees - 3, 6. Rare. On sandy soil and swamp site close to railway; on sedge-Sphagnum wetland.
Sphagnum wulfianum Girg. - 3. On soil in pine forest.

Stereodon Pallescens (Hedw.) Mitt. - 1-6. Frequent. On decaying wood, at the base of trunks, on tree bark in lime, mixed broadleaved, spruce, floodplain black alder forests. With sporophytes.

SYNTRICHIA RURALIS (Hedw.) F.Weber \& D.Mohr 1. Rare. On bare soil of roadsides; on stone at limestone; on bare soil close to quarry.

Tetraphis PEllucida Hedw. - 1-6. Frequent. On decaying wood in dry pine-spruce forests; less frequent at the base of trunks in lime, mixed broad-leaved, spruce and floodplain forests. With sporophytes.

Thuidium Recognitum (Hedw.) Lindb. - 1, 5. Rare. On soil in spruce forest; on rubbly slope; on dolomite stone at the quarry.

TORTUla muralis Hedw. var. AESTIVA Hedw. -1 . Rare. On stone at river bank. With sporophytes.

Trematodon ambiguus (Hedw.) Hornsch. - 1, 3. Rare. On dolomite stone at the quarry; on bare soil in disturbed habitats. With sporophytes.

WARnSTORFIA EXANNULATA (Bruch, Schimp. \& W.Gümbel) Loeske - 1, 4. Rare. On dead driftwood in water in swamp forest; in streams. With sporophytes.

WARnstorfia fluitans (Hedw.) Loeske - 3, 6. Sporadically. On river and streams banks; in ditches; in hollows of sedge-Sphagnum wetland; in birch forest. With sporophytes.

\section{DISCUSSION}

In total 23 liverwort and 142 moss species were found in the present study. The revealed bryophyte species composition is rather typical for the central part of European Russia. Comparison of bryophyte species diversity of adjacent reserves in this region (Ignatov et al., 2004; Kostantinova, 2004; Grishutkina, 2008) (Table 1 ), having comparable areas and landscapes, points at rather complete inventory of the flora of Mordovia State Nature Reserve. This comparison demonstrates dependence of bryophyte species diversity from zonal position. The reserves located in north forest steppe subzone, having dryer climate and lower diversity of plant communities and habitats (Galichja Gora Reserve, Voronezhsky Reserve), are poor in bryophyte species whereas the reserves located in decidous 
Table 1. Bryophyte species diversity in reserves of the central part of European Russia

\begin{tabular}{llcc}
\hline Reserve & Region & $\begin{array}{c}\text { Number of } \\
\text { moss species }\end{array}$ & $\begin{array}{r}\text { Number of liv- } \\
\text { erworts species }\end{array}$ \\
\hline Mordovia State Reserve & Republic of Mordovia & 142 & 23 \\
Kerzhinsky Reserve & Nizhniy Novgorod Region & 164 & - \\
Oksky Reserve & Ryazan Region & 154 & 27 \\
Volzhsko-Kamsky Reserve & Republic of Tatarstan & 153 & 33 \\
Bolshaya Kokshaga Reserve & Republic of Mari El & 149 & - \\
Prioksko-Terrasny Reserve & Moscow Region & 134 & 22 \\
Tsentral'no-Chernozemny Reserve & Kursk Region & 132 & 12 \\
Reserve «Galichya Gora» & Lipetsk Region & 129 & 9 \\
Zhigulevsk Reserve & Samara Region & 125 & 10 \\
Voronezh Reserve & Voronezh Region & 119 & 11 \\
National Park «Smol'nyy» & Republic of Mordovia & 128 & 13 \\
\hline
\end{tabular}

coniferous subzone with more humid climate, diverse plant communities and habitats have more bryophyte species in the flora. Kerzhinsky Reserve, which is located in deciduous-conifereous forest subzone, have highest bryophyte species diversity due to humid climate and high habitat diversity. Recorded liverwort species diversity in the middle of European Russia is rather low and in our opinion needs further special study aimed at search of their specific habitats. Collections of liverworts in Mordovia State Nature Reserve were incomplete and are not included in discussion section.

Distribution of moss species numbers in substrate groups is given in the Table 2. Mosses collected from ground floor represent the most species rich substrate group (54 species). Typical epigeic mosses are Dicranum polysetum, $D$. scoparium, Hylocomium splendens, Plagiomnium cuspidatum, Pleurozium schreberi. Ground floor represents the different habitat (coniferous versus deciduous) and microtopography types (depressions versus elevation) and rather stable conditions for bryophyte establishment and therefore may cause the highest bryophyte richness in contrast to other substrates.

On decaying wood and on tree bases were found 52 and 46 moss species respectively. Most common species of decaying wood are Amblystegium serpens, Brachytheciastrum velutinum, Brachythecium salebrosum, Callicladium haldanianum, Campylidium sommerfeltii, Sanionia uncinata, Sciuro-hypnum reflexum, Stereodon pallescens. The following mosses are most char- acteristic for basal part of tree trunks: Anomodon longifolius, Bryum moravicum, Dicranum flagellare, D. montanum, Plagiothecium denticulatum, $P$. laetum. In total 27 moss species were collected from the bark of trees, where the most common are Homalia trichomanoides, Leskea polycarpa, Neckera pennata, Pseudoleskeella nervosa, Pylaisia polyantha. Records of rare and interesting moss species Dicranum viride, Leucodon sciuroides, Pylaisia selwynii are noteworthy.

Wood represents more specific substrate for bryophyte establishment, than ground floor. Dead logs and living tree stems are as the dynamic islands for bryophyte establishment, although ensuring specific environment for rare species establishment, which are not found on other substrates.

On bare soil of disturbed habitats (roadsides, pits, under roots of fallen trees) 52 species were found. They are usually characteristic for this substrate only. More common species of such habitats are Atrichum tenellum, A. undulatum, Bryum lonchocaulon, Dicranella heteromalla, Fissidens bryoides, Mnium stellare, Pohlia annotina. On bare soil rare species Buxbaumia aphylla, Physcomitrella patens, Physcomitrium sphaericum, Schistostega pennata, Trematodon ambiguus were found. Bare soil offers establishment of pioneer bryophyte species, which starts the succession and forming of vegetation on this substrate type.

Limestone bank of Satis River represents the only place in the reserve where limestone outcrops occur, 19 species of mosses were 
Table 2. Number of moss species of different substrates

\begin{tabular}{lcl}
\hline Substrates & $\begin{array}{l}\text { Number } \\
\text { of species }\end{array}$ & $\begin{array}{l}\% \text { of the } \\
\text { flora }\end{array}$ \\
\hline Ground floor & 54 & $38.3 \%$ \\
Decaying wood & 52 & $36.8 \%$ \\
Tree bases & 46 & $32.6 \%$ \\
Bark of tree & 27 & $19.1 \%$ \\
Stones & 19 & $13.5 \%$ \\
Banks of streams and rivers & 28 & $19.8 \%$ \\
Bare soil & 52 & $36.8 \%$ \\
\hline
\end{tabular}

found here on stones, among them Campylidium calcareum, Fissidens gracilifolius, Didymodon rigidulus. The banks of streams and rivers represent quite specific bryophyte habitat. In total 26 moss species were collected there. Most common species of wet soils on river and stream banks are Calliergon cordifolium, Leptodictyum riparium, Plagiomnium ellipticum. In water Warnstorfia exannulata and Warnstorfia fluitans were collected.

Eight species of mosses found in the study area are included in the Red Data Book of Mordovia (2003). They are Aulacomnium palustre, Buxbaumia aphylla, Campyliadelphus chrysophyllus, Fissidens bryoides, Neckera pennata, Physcomitrella patens, Sphagnum palustre, S. riparium. According to our observations and literature data (Ignatov et al., 2006), most of them are more or less widespread in the Russian Plain, except Campyliadelphus chrysophyllus and Physcomitrella patens. In our opinion they should be excluded from the next edition of the Red Data Book of Mordovia. On the other hand, we have found Dicranum viride, Fissidens exiguus, F. gracilifolius, Physcomitrium sphaericum, Pterigynandrum filiforme, Trematodon ambiguus, which are rare in the central part of European Russia and previously not recorded for the Republic of Mordovia. We recommend to include them in the next edition of the Red Data Book of Mordovia. Occurrence of these species in the strictly protected territory of Mordovia State Nature Reserve is noteworthy.

\section{ACKNOWLEDGEMENTS}

We are grateful to two anonymous reviewers and the editors for the careful reading of the manuscript, valuable questions, corrections and ad- vices. The present study was carried out within the framework of the institutional research project (no. 01201255616) of the Komarov Botanical Institute of the Russian Academy of Sciences and with the practical and financial support from Mordovia State Nature Reserve.

\section{REFERENCES}

Czernyadjeva, I.V. 2016a. New moss records from Republic of Mordovia. 1. - In: Sofronova E.V. (ed.) New bryophyte records. 7. Arctoa 25(1): 194-195.

Czernyadjeva, I.V. 2016b. New moss records from Republic of Mordovia. 3. - In: Sofronova E.V. (ed.) New bryophyte records. 7. Arctoa 25(2): 432.

Czernyadjeva, I.V. \& Mežaka A. 2016. The bryoflora of the lime forest of Mordovskii State Reserve. Proceedings of the Mordovskii State Reserve. 17. Saransk, Pushta: 219-230. (In Russian).

Damsholt, K. 2002. Illustrated Flora of Nordic liverworts and hornworts. Lund, $840 \mathrm{p}$.

Gafferberg, I.G. 1960. Mordovskii State Reserve. Proceedings of the Mordouskii State Reserve. Saransk. 1: 5-24. (In Russian).

Grishutkin, O.G., Boychuk, M.A., Grishutkina, G.A. 2016. New moss records from Republic of Mordovia. 2. - In: Sofronova E.V. (ed.) New bryophyte records. 7. Arctoa 25(1): 195. (In Russian).

Grishutkina, G.A. 2008. List of bryophyte of the National Park "Smol'nyy" - Proceedings of the National Park "Smol'nyy". 1: 58-68. (In Russian).

Ignatov, M.S., Ignatova, E.A., Pronkina, G.A. 2004. Mosses. - In: The present-day state of biological diversity within protected areas. Moscow. Pp. 274-366. (In Russian).

Ignatov, M.S., Afonina, O.M., Ignatova, E.A., Abolina, A., Akatova, T.V., Baisheva, E.Z., Bardunov, L.V., Baryakina, E.A., Belkina, O.A., Bezgodov, A.G., Boychuk, M.A., Cherdantseva, V.Ya., Czernyadjeva, I.V., Doroshina, G.Ya., Dyachenko, A.P., Fedosov, V.E., Goldberg, I.L., Ivanova, E.I., Jukoniene, I. , Kannukene, L., Kazanovsky, S.G., Kharzinov, Z.Kh., Kurbatova, L.E., Maksimov, A.I., Mamatkulov, U.K., Manakyan, V.A., Maslovsky, O.M., Napreenko, M.G., Otnyukova, T.N., Partyka, L.Ya., Pisarenko, O.Yu., Popova, N.N., Rykovsky, G.F., Tubanova, D.Ya., Zheleznova, G.V., Zolotov, V.I. 2006. Check-List of mosses of East Europe and North Asia. - Arctoa 15: 1-130. https://doi.org/10.15298/arctoa.15.01

Khapugin, A.A., Chugunov, G.G., Vargot, E.V. 2011. Buxbaumia aphylla Hedw. (Bryophyta) in Gushta forestry of the Mordovskii State Nature Reserve named P. G. Smidovich. - Proceedings of the Mordouskii State Reserve. Saransk. IX: 224-231. (In Russian).

Konstantinova, N.A. 2004. The Anthocerotae and Hepaticae. - In: The present-day state of biological diversity within protected areas. Moscow. Pp. 236-273. (In Russian). 
Kurnaev, S.F. 1968. The main forest types of middle part of the Russian Plain. Moscow. 355 pp. (In Russian).

Kuznetsov, N. I. 1960a. Flora of fungus, lichen, mosses and vascular plants of the Mordovskii Reserve. - Proceedings of the Mordouskii State Reserve. Saransk. 1: 71-128. (In Russian).

Kuznetsov, N. I. 1960b. Vegetation of the Mordovskii State Reserve. Proceedings of the Mordouskii State Reserve. Saransk. 1: 129-220. (In Russian).

Mežaka, A. 2015. Dicranum viride - rare and new species for Mordovskii Reserve. Proceedings of the Mordovskii State Reserve. 14. Saransk, Pushta: 216-218. (In Russian).
Mežaka, A., Potemkin, A.D., Urbanavichene, I.N., Urbanavichus, G.P. 2013. New liverwort records from Mordovia Republic. 1. - In: Sofronova E.V. (ed.) New bryophyte records 2. Arctoa 22: 247.

Mežaka, A. \& Potemkin, A.D. 2015. New liverwort records from Mordovia Republic. 2. - In: Sofronova E.V. (ed.) New bryophyte records 4. Arctoa 24(1): 243.

Potemkin, A.D. \& Sofronova, E.V. 2009. Liverworts and hornworts of Russia. Saint Petersburg, Yakutsk, 368 pp. (In Russian and English).

Red Data Book of the Republic of Mordovia. 2003. Vol. 1 Rare species of plants, lichens and fungi. Saransk. 288 pp. (In Russian). 
82 Folia Cryptog. Estonica 